\title{
POSSIBILITIES OF BIOGAS PRODUCTION FROM LIVESTOCK WASTE IN LATVIA
} Janis Millers' ${ }^{1}$ Mg.oec.; Irina Pilvere ${ }^{2}$, Dr.oec.

\section{1, 2 Latvia University of Life Sciences and Technologies}

Abstract. With the adoption of the Green Deal in the European Union (EU), the role of biodiversity, basic principles of the circular economy, climate change mitigation, forest protection and renewable energy increased. Since 2007, biogas production in Latvia has increased significantly, as it was possible to receive co-funding from the EU Funds for the construction of biogas plants. In 2021, inputs of agricultural origin are used by 40 biogas plants with an average installed capacity of $1 \mathrm{MW}$. The emergence of biogas plants on livestock farms is facilitated by the development of a circular economy producing waste from the production process - manure and feed waste. Anaerobic fermentation results in digestate - a nutrient-rich plant fertilizer that reduces the application of chemical fertilizers. Rational use of biogas can reduce the need for fossil fuels. Energy production from biogas should be encouraged, as waste is used efficiently, thereby generating energy and reducing the release of greenhouse gases into the atmosphere. In Latvia, livestock production is one of the key industries of the national economy, which produces manure and feed waste. The present research calculated the amounts of cattle, pig and poultry manure and feed waste in Latvia. The research analysed livestock farms by number of cattle, pigs and poultry, the potential amounts of manure and waste produced and theoretical biogas output. Theoretically, 309 farms analysed can produce $93.5 \mathrm{mln} . \mathrm{m}^{3}$ of biogas from agricultural waste and construct 269 new biogas plants. A policy for supporting the construction of new biogas plants would contribute to the country's independence from fossil energy sources, as well as increase the proportion of renewable energy sources to $50-70 \%$ in final energy consumption by 2030 . Farmers on whose farms a biogas plant could be built need to carefully consider the uses of the biogas produced. The uses could be thermal energy generation for heat supply, cogeneration (thermal and electrical energy) or biomethane production.

Keywords: biogas, agricultural waste, livestock manure, bioenergy

JEL code: Q15, Q56.

\section{Introduction}

European Member States are committed both to increase their share of renewable energy sources and to reduce their Greenhouse Gases (GHG) emissions (European Parliament and..., 2009). Within the Renewable Energy Directive,2009/28 EC mandatory sustainability criteria are defined for biofuels, but only voluntary recommendations were defined for biomass used for power and heat production.

In Latvia, the National Energy and Climate Plan was approved on 4 February 2020. In 2030, it is planned to ensure at least $50 \%$ of the share of renewable energy in Latvia's final energy consumption (Par Latvijas Nacionalo..., 2020).

Agricultural anaerobic digestion serves not only in electricity and heat production, but also in production of nutrient rich digestate stream, that is the side product of anaerobic digestion plant. As a side product for energy produced (in the form of biogas), anaerobic digestion facilities generate significant quantities of collateral biomass known as digestate which is often recycled to soil as fertilizer (Risberg et al., 2017; Slepetiene et al., 2020).

In the context of the circular economy model, the biogas production has been highlighted as a versatile renewable energy source that could be used to replace fossil fuels and heat by reducing greenhouse gases emissions (Potting et al., 2017). Biogas can be produced from a wide range of raw materials, from organic waste to dedicated energy crops, and can be utilised for various energy services such as heat, combined heat and power or as a vehicle fuel. Biogas systems are therefore affected by a number of different incentives and barriers, including energy-, waste treatment - and agricultural policies Lantz et al., 2007). 
Large-scale biogas generation is a well-established technology in developed countries. However, there is a shortage of research on these large-scale systems in developing countries. To achieve suitable biogas production, some challenges need to be surpassed such as construction materials and models, efficiency, and performance (Ahlberg-Eliasson, 2017). The biogas produced can be transformed onsite into heat and energy (Boulamanti et al., 2013; Agostini et al., 2015) or domestic activities (Russo, von Blottnitz, 2017).

The biogas end use option is important when environmental benefits of its production are considered, especially the kind of energy production systems it replaces (Patterson et al., 2011; Poeschl et al., 2012). Biogas injection into the natural gas distribution network is one of the most promising opportunities (Poeschl et al., 2010; Uusitalo et al., 2013), but is only possible when the network is close to the production plant. Despite being the most adequate raw material in terms of reducing GHG emissions, manure has low energy value, due to its low organic matter content and high ammonium concentration (Regueiro et al., 2012).

By means of adapted management and configuration, biogas plants can supply electricity on demand and, through the substitution of power production from fossil fuels, avoid $\mathrm{CO}_{2}$ emissions (Hahn et al., 2015). Some researchers analysed the GHG emissions mitigation costs for biogas plants in Germany and found a wide range of potential $\mathrm{CO}_{2}$ mitigation costs from 95378 EUR per tonne (Scholzet al., 2011 ).

The authors of the paper draw attention to the amount of manure from cattle, pigs and poultry as well as spoiled fodder. Methane is one of the greenhouse gases that inevitably results from agricultural activity. The research investigates how much biogas could be obtained from the largest cattle farms (200 and more cattle), pig farms (400 and more pigs), and poultry farms (50000 and more poultry) in Latvia. Farms with fewer livestock were not considered because the amount of manure was not enough to set up a biogas plant next to them. For example, all Danish biogas plants have increased gas production as a result of admixing industrial organic wastes with manure. This is predominantly regarded as a great advantage for both biogas plants and waste suppliers (Mæng et al., 1999).

Hypothesis of the research: in Latvia, there is unused agricultural waste potential to produce biogas from manure and feed waste from animal production.

The aim of the research is to identify the amount of biogas to be theoretically produced by cattle, pig and poultry farms from feed waste in Latvia.

Research tasks: 1) to analyse livestock farms by number of animals and identify the potential amount of manure produced by the farms, as well as the potential amount of feed waste from animal production in Latvia; 2) to calculate the theoretical amount of biogas from manure and feed waste in Latvia; 3) to determine the number of biogas plants to be needed to produce biogas in Latvia.

Research methods. The research used literature review and empirical research methods, while information and data were derived from various sources: national institutions - the Central Statistical Bureau, the Ministry of Agriculture, the Agricultural Data Centre, the Rural Support Service -, research studies by national and foreign scientists, analytical reports, publications and researches related to the agricultural industry. The research used the methods of comparison, analysis, synthesis, induction etc. for selecting and grouping the data and identifying the similarities and differences.

The novelty of the research is to determine the amount of unused manure and feed waste to be used for biogas production is still available in Latvia. 


\section{Research results and discussion}

\section{Potential amounts of agricultural biomass waste and biogas to be produced in Latvia}

The main sources of agricultural biomass in livestock production are: 1) manure; 2) miscellaneous unused feed residues. To calculate the potential amount of waste from livestock production in Latvia, the research used data on livestock density on a farm to identify the amount of waste produced and whether it is advantageous to build a biogas plant, as well as on manure per livestock unit and potential feed loss in livestock production. The research selected the following main industries having potential to establish biogas plants in Latvia: cattle, pig and poultry production.

Cattle. As at the beginning of July 2020, 416003 cattle on more than 17 thou. farms were registered in Latvia. Of the total cattle, 199777 or $48 \%$ were dairy cows and 34812 or $8.3 \%$ were calves (Agricultural Data Centre, 2020). The rest of cattle - 187839 or $43.3 \%$ - were beef cattle, breeding bulls and suckler cows with calves. The calculations assumed that biogas plants could be installed only on the farms with a sufficient cattle density and a sufficient amount of manure to be produced. Therefore, the amount of manure was calculated for farms with more than 200 cattle. There were 267 such farms in Latvia, representing $1.6 \%$ of the total number of cattle farms; however, the farms kept $32.4 \%$ of the total cattle. In addition, farms with 300 cattle accounted for only $0.9 \%$ of the total number of farms and kept $25.4 \%$ of the total cattle (Table 1 ).

Table 1

Number of farms with over 200 cattle in Latvia at the end of 2019

\begin{tabular}{|l|c|c|c|c|}
\hline \multirow{2}{*}{ Number of cattle } & \multicolumn{2}{|c|}{ Farms in the respective group } & \multicolumn{2}{c|}{ Total cattle in the respective group } \\
\cline { 2 - 5 } & number & $\%$ & number & $\%$ \\
\hline $\mathbf{2 0 0 - 2 9 9}$ & 114 & 0.7 & 27557 & 7.0 \\
\hline $\mathbf{3 0 0 - 4 9 9}$ & 79 & 0.5 & 30064 & 7.6 \\
\hline $\mathbf{5 0 0}$ and more & 74 & 0.4 & 70369 & 17.8 \\
\hline Total & $267 / 17064$ & $1.6 / 100.0$ & $127990 / 395320$ & $32.4 / 100.0$ \\
\hline
\end{tabular}

Source: authors' calculations based on the Central Statistical Bureau, 2021 .

Both litter manure and slurry can be produced by dairy farms. Litter manure is produced if a relatively large amount of litter is used to clean livestock housing facilities. This is typical of the facilities where cows are tethered in tie-stalls, as approximately $2 \mathrm{~kg}$ of straw per day need to be to spread over such a tie-stall. Such manure is also obtained from calf pens and calving stalls. It should be taken into account when considering storing litter manure that in addition to solid manure, slurry is also obtained, which needs to be stored in a separate facility. Each dairy cow with a milk yield of 6000-8000 kg/year produces 15 tonnes of litter manure and 19 tonnes of liquid manure, i.e. a total of 34 tonnes of manure per year (Karklins, 2019; Ministry of Agriculture, 2008). Cattle manure can produce 8-25 $\mathrm{m}^{3}$ (on average $20 \mathrm{~m}^{3}$ ) of biogas (SEA, 2015). The theoretical output of biogas from the manure of almost 128 thou. cattle kept on 267 farms with more than 200 cattle is a little more than $68 \mathrm{mln} . \mathrm{m}^{3}$ per year (Table 2). 
Potential amounts of manure and biogas output per year for farms with more than 200 cattle in Latvia at the end of 2019

\begin{tabular}{|l|c|c|c|c|}
\hline \multicolumn{1}{|c|}{ Kind of cattle } & Number & $\begin{array}{c}\text { Amount of manure } \\
\text { per cattle } \\
\text { per year, } \mathbf{t}\end{array}$ & $\begin{array}{c}\text { Amount of } \\
\text { manure } \\
\text { per year, t }\end{array}$ & $\begin{array}{c}\text { Theoretical } \\
\text { biogas } \\
\text { output, } \mathbf{m}^{\mathbf{3}}\end{array}$ \\
\hline Dairy cows & 31917 & 34 & 1085178 & 21703560 \\
\hline $\begin{array}{l}\text { Beef cattle, breeding } \\
\text { bulls, suckler cows } \\
\text { with calves }\end{array}$ & 81052 & 25 & 2026300 & 40526000 \\
\hline Calves & 15021 & 20 & 300420 & 6008400 \\
\hline Total & 127990 & $\mathrm{x}$ & 3411898 & 68237960 \\
\hline
\end{tabular}

Source: authors' calculations based the Central Statistical Bureau, 2021a.

Pigs. In July 2020, 323348 pigs were registered in Latvia, of which 141840 or $43.8 \%$ were fattening pigs, 53801 or $16.6 \%$ were dairy piglets, 23976 or $7.4 \%$ were sows, 420 or $0.12 \%$ were breeding boars and 103330 or $31.9 \%$ were other pigs (young pigs, gilts, weaned piglets) (Agricultural Data Centre, 2020).

Number of farms with more than 400 pigs in Latvia at the end of 2019

\begin{tabular}{|l|c|c|c|c|}
\hline \multirow{2}{*}{ Number of pigs } & \multicolumn{2}{|c|}{ Farms in the respective group } & \multicolumn{2}{c|}{ Total pigs in the respective group } \\
\cline { 2 - 5 } & number & $\%$ & number & 1.4 \\
\hline $\mathbf{4 0 0 - 9 9 9}$ & 6 & 0.2 & 4544 & 1.4 \\
\hline $\mathbf{1 0 0 0 - 1 9 9 9}$ & 3 & 0.1 & 4393 & 9.8 \\
\hline $\mathbf{2 0 0 0 - 4 9 9 9}$ & 11 & 0.4 & 30742 & 81.7 \\
\hline $\mathbf{5 0 0 0}$ and more & 15 & 0.5 & 256576 & $94.3 / 100.0$ \\
\hline Total & $35 / 2772$ & $1.2 / 100.0$ & $296255 / 314204$ & $\%$ \\
\hline
\end{tabular}

Source: authors' calculations based the Central Statistical Bureau, $2021 b$.

Of the total pigs, $94.3 \%$ were kept by 35 farms or $1.2 \%$ of a total of 2772 pig farms. The analysis of the data took into account the farms with more than 400 pigs (Table 3 ).

Table 4

Potential amounts of manure and biogas output for farms with more than 400 pigs in Latvia

\begin{tabular}{|l|c|c|c|c|}
\hline \multicolumn{1}{|c|}{ Kind of pigs } & Number & $\begin{array}{c}\text { Amount of } \\
\text { manure } \\
\text { per pig } \\
\text { per year, t }\end{array}$ & $\begin{array}{c}\text { Amount } \\
\text { of manure } \\
\text { per year, t }\end{array}$ & $\begin{array}{c}\text { Theoretical } \\
\text { biogas } \\
\text { output, m }\end{array}$ \\
\hline Fattening pigs (30-100 kg) & 130973 & 3.0 & 392919 & 6286704 \\
\hline Sows with piglets & 22613 & 4.0 & 90452 & 1447232 \\
\hline Piglets (7.5-30 kg) & 50326 & 0.65 & 32712 & 523392 \\
\hline Boars & 395 & 5.0 & 1975 & 31600 \\
\hline Young pigs, gilts, weaned piglets & 92343 & 2.3 & 212389 & 3398222 \\
\hline Total & 296428 & $\mathrm{X}$ & 730844 & 11687150 \\
\hline
\end{tabular}

Source: authors' calculations based on the Ministry of Agriculture of the Republic of Latvia, 2008.

One ton of pig manure can produce 8-22 $\mathrm{m}^{3}$ (on average $16 \mathrm{~m}^{3}$ ) of biogas (SEA, 2015). Summing up the potential amounts of manure from farms with more than 400 pigs and multiplying it by the biogas 
potential per tonne of manure reveals that more than $11.7 \mathrm{mln} . \mathrm{m}^{3}$ of biogas could be produced per year (Table 4).

Poultry. Poultry produces less manure than cattle or pigs; however, the theoretical biogas output from poultry manure is higher, $21-84 \mathrm{~m}^{3} / \mathrm{t}$ (on average $55 \mathrm{~m}^{3} / \mathrm{t}$ ) (SEA, 2015). This is due to the higher dry matter content of poultry manure. The amount of poultry manure per poultry varies, depending on the poultry species, age, type of housing and diets, type of feed and other factors. Laying hens produce 0.03 tonnes of litterless manure per year (Agricultural Data Centre, 2020).

In July 2020, 5621631 poultry, not grouped by species, were registered in Latvia. Let us assume that on average each poultry produces 0.025 tonnes of manure per year. Seven farms with more than 50000 poultry kept a total of 4569900 poultry or $88.6 \%$ of the total poultry in the country (Central Statistical Bureau, 2021d). Per year, 4569900 poultry could produce 114247 tonnes of manure. The theoretical output of biogas could be $6283585 \mathrm{~m}^{3}$ per year.

Fodder crop waste from cattle farms. Fodder and green fodder crops (maize for silage and green fodder, perennial grasses, nectar plants) occupied 300.7 thou. ha in Latvia in 2019. Perennial grasslands occupied 273.3 thou. ha, while 25.4 thou. ha were cropped with maize. Forage and silage crops, other than maize, occupied 2 thou. ha in 2019 (Central Statistical Bureau, 2021c).

Table 5

Areas under fodder crops and yields in 2019 as well as the potential amount of biogas production from feed waste in Latvia

\begin{tabular}{|l|c|c|c|c|c|c|}
\hline \multicolumn{1}{|c|}{ Crop } & $\begin{array}{c}\text { Sown } \\
\text { area, } \\
\text { thou. ha }\end{array}$ & $\begin{array}{c}\text { Output, } \\
\text { thou. t }\end{array}$ & $\begin{array}{c}\text { Feed for } \\
\text { farms with } \\
\mathbf{2 0 0} \text { cattle, } \\
\text { thou. t }\end{array}$ & $\begin{array}{c}\text { Average } \\
\text { amount } \\
\text { of waste, \% }\end{array}$ & $\begin{array}{c}\text { Potential } \\
\text { amount } \\
\text { of waste, } \\
\text { thou. t }\end{array}$ & $\begin{array}{c}\text { Theoretical } \\
\text { biogas } \\
\text { output, m }\end{array}$ \\
\hline $\begin{array}{l}\text { Maize for } \\
\text { fodder }\end{array}$ & $21.4 *$ & $725.9 *$ & 254.7 & 15 & 38.2 & 4202000 \\
\hline $\begin{array}{l}\text { Perennial } \\
\text { grasses }\end{array}$ & 273.3 & 396.6 & 128.3 & 10 & 12.83 & 1411300 \\
\hline $\begin{array}{l}\text { Other } \\
\text { forage } \\
\text { crops }\end{array}$ & 2.0 & 29.3 & 9.5 & 15 & 1.42 & 156200 \\
\hline $\begin{array}{l}\text { Meadow } \\
\text { and } \\
\text { pasture } \\
\text { hay }\end{array}$ & - & 437.7 & 141.5 & 10 & 14.1 & 1551000 \\
\hline Total & 296.7 & 1651.1 & 534.0 & & & \\
\hline
\end{tabular}

* 4 thou. ha under maize are used for biogas production (Rural Support Service, 2021), therefore the total area and the total output of maize for fodder is reduced proportionally.

\section{Source: authors' calculations based the Central Statistical Bureau, $2021 \mathrm{c}$.}

The area sown with maize for fodder was 21.4 thou. ha because in the database of the Rural Support Service, 4 thou. ha were declared for direct payments as areas for biogas production from maize; therefore, it could be assumed that the maize yield did not change, depending on the kind of use. In 2019 in Latvia, the total maize output was 861.7 thou. tonnes, yet in proportion to the forage area - 725.9 thou. tonnes. In 2019, the output of perennial grass hay was 396.6 thou. tonnes, the output of meadow and pasture hay was 437.7 thou. tonnes, while the output of green fodder and silage crops other than maize was 29.3 thou. tonnes. Unfortunately, the statistical sources did not classify farms by area of fodder crops grown, yet the research assumed that the mentioned kinds of fodder were used by cattle farms. Since the farms with more than 200 cattle represented $32.4 \%$ of the total cattle had the potential for biogas production, it was assumed that such a proportion would be the basis for calculations for biogas production from fodder. 
Of the total silage that was harvested at the right time and acidified according to the technology, $10-20 \%$ (on average $15 \%$ ) was fodder waste (Priekulis, 2012). Feed waste includes that part of the feed which has been damaged in the silage pit for various reasons. The other part of feed waste represents feed residues. A tonne of grass and maize waste with a dry matter of $20-30 \%$ is able to produce $55-128 \mathrm{~m}^{3}$ and $68-170 \mathrm{~m}^{3}$ of biogas, respectively (SEA, 2015), which is on average $110 \mathrm{~m}^{3} / \mathrm{t}$.

Calculating feed waste in proportion to the number of cattle analysed, 3-4 kg of feed dry matter per $100 \mathrm{~kg}$ of live weight per day is required per cattle (SEA, 2015). Maize accounts for $80 \%$ and grass silage for $85 \%$ of the total silage prepared on farms, as $15 \%$ and $10 \%$, respectively, are fodder waste. Based on this pattern, one can calculate the amount of feed waste produced by farms with 200 and more cattle.

Table 5 summarizes the calculations of the potential amount of feed that could be used in cattle production. Based on the total crop output, the output of crops sown on farms with 200 and more cattle was calculated proportionally. Accordingly, based on the assumptions about the amount of fodder wasted, the calculation shows that each year the amount is a little more than 66 thou. tonnes. If this amount were used for biogas production, the theoretical output of biogas from feed waste would be $7.32 \mathrm{mln} . \mathrm{m}^{3}$.

In pig and poultry production, however, feed consumption cannot be calculated due to the lack of data on its structure and uses.

\section{Potential justification for building biogas plants}

Agricultural waste is an important resource for increasing the energy efficiency of businesses. It is the most advantageous to recycle agricultural waste in the vicinity of the farm, saving on logistics costs.

The potential output of biogas from cattle, pig and poultry manure as well as cattle feed waste is $93.5 \mathrm{mln} . \mathrm{m}^{3}$ (Tables 2, 4, 5 and calculations of poultry production); besides, $7.8 \%$ could be produced from unused fodder in cattle production, while $92.2 \%$ from manure in cattle, pig and poultry production.

Table 6

Potential distribution of biogas output for various groups of cattle farms in Latvia

\begin{tabular}{|l|c|c|c|c|}
\hline $\begin{array}{c}\text { Number of } \\
\text { cattle }\end{array}$ & $\begin{array}{c}\text { Farms in the } \\
\text { respective } \\
\text { group }\end{array}$ & $\begin{array}{c}\text { Distribution of } \\
\text { biogas from } \\
\text { manure, } \mathbf{~ m}^{\mathbf{3}}\end{array}$ & $\begin{array}{c}\text { Distribution of } \\
\text { biogas from feed } \\
\text { residues, } \mathbf{~ m}^{\mathbf{3}}\end{array}$ & $\begin{array}{c}\text { Amount of biogas per } \\
\text { farm in the } \\
\text { respective group, } \mathbf{m}^{\mathbf{3}}\end{array}$ \\
\hline $\mathbf{2 0 0 - 2 9 9}$ & 114 & 14692034 & 1576146 & 142703 \\
\hline $\mathbf{3 0 0 - 4 9 9}$ & 79 & 16028643 & 1719538 & 224661 \\
\hline $\begin{array}{l}\mathbf{5 0 0} \text { and } \\
\text { more }\end{array}$ & 74 & 37517283 & 4024816 & 561380 \\
\hline Total & 267 & 68237960 & 7320500 & 282990 \\
\hline
\end{tabular}

Source: authors' calculations

On cattle farms, biogas is produced from cattle manure and feed waste. The amount of biogas per farm in the respective group is calculated proportionally.

On farms with 200-299 cattle, the annual output of biogas totals $142703 \mathrm{~m}^{3}$. With such a biogas output, it would be the most advantageous for the farm to use the biogas produced for heat production for the farm itself. It is also possible to purify biogas to biomethane and store it compressed for later use for heating or transport (for self-consumption).

On farms with 300-499 cattle, the output of biogas per year totals $224661 \mathrm{~m}^{3}$. Such an amount of biogas would be enough for running a $50 \mathrm{~kW}$ cogeneration plant, and the heat and electricity produced would be used for self-consumption on the farm. An alternative would be to purify the biogas to biomethane and store it compressed for road transport or heat generation or to sell it. 
On farms with 500 and more cattle, the annual output of biogas is $561380 \mathrm{~m}^{3}$. This amount of biogas is enough to run a $140 \mathrm{~kW}$ cogeneration plant. It would be possible to generate $3.4 \mathrm{MWh}$ of electricity per day or 1.2 TWh per year by such a cogeneration plant. The amount of heat depends on the equipment of the cogeneration plant; however, it would not be less than the amount of electricity generated. The cattle farms of this group would have to purify biogas to biomethane and compress it to use for running their farm machinery or sell the biomethane. If the farms chose to have no cogeneration plant, part of the gas produced should also be used for heating enzymes.

Potential distribution of biogas output for various groups of pig farms in Latvia

\begin{tabular}{|l|c|c|c|}
\hline Number of pigs & $\begin{array}{c}\text { Farms in the } \\
\text { respective } \\
\text { group }\end{array}$ & $\begin{array}{c}\text { Distribution of biogas } \\
\text { from manure, } \mathbf{~ m}^{\mathbf{3}}\end{array}$ & $\begin{array}{c}\text { Amount of biogas per farm in } \\
\text { the respective group } \mathbf{~ m}^{\mathbf{3}} \mathbf{\text { year }}\end{array}$ \\
\hline $\mathbf{4 0 0 - 9 9 9}$ & 6 & 179259 & 29876 \\
\hline $\mathbf{1 0 0 0 - 1 9 9 9}$ & 3 & 173302 & 57767 \\
\hline $\mathbf{2 0 0 0 - 4 9 9 9}$ & 11 & 1212760 & 110250 \\
\hline $\mathbf{5 0 0 0}$ and more & 15 & 10121828 & 674788 \\
\hline Total & 35 & 11687150 & 333919 \\
\hline
\end{tabular}

Source: authors' calculations

The amount of biogas produced by farms with 400-1999 pigs is relatively small; therefore, the biogas from manure could be used for producing hot water and heating the farms.

The amount of biogas produced from manure by farms with 2000-4999 pigs is sufficient to be purified to biomethane. The further uses of it are heating and transport fuel or compressed biomethane could be sold.

On farms with 5000 and more pigs, the amount of biogas produced from manure is enough to run a cogeneration plant with a capacity of $160 \mathrm{~kW}$. An investment in a cogeneration facility is larger than if burning biogas in boilers; therefore, the cogeneration facility should be in operation all year round, also due to the need to heat the fermenter so that fermentation does not stop.

There were 7 farms with more than 50000 poultry in Latvia. The theoretical output of biogas totals $6.3 \mathrm{mln} . \mathrm{m}^{3}$ of biogas, while on average per farm $-897655 \mathrm{~m}^{3}$. Theoretically, this amount of biogas allows operating a cogeneration plant with a capacity of $0.22 \mathrm{MW}$. Potential scenarios for the farms to use the biogas produced are similar to those for cattle and pig farms.

After analysing the locations of cattle (200 cattle and more), pig (400 pigs and more) and poultry farms (50000 poultry and more) in Latvia (Nipers et al., 2019), it could be stated that the farms were located throughout the country. From an economic perspective, there would be no economic justification for building a biogas plant on each farm. It would be necessary to examine in more detail what kind of farms with an adequate number of livestock could cooperate for constructing a joint biogas plant, if the distance between them does not exceed $15 \mathrm{~km}$, thereby ensuring rational use of both raw material resources and the biogas produced.

The total number of livestock farms that could be involved in the processing of biomass (waste) of agricultural origin would be 309 (including 267 cattle, 35 pig and 7 poultry) farms. This means that the maximum number of biogas plants could be 309, yet it should be taken into account that in 2021 biogas cogeneration plants with a total electrical capacity of $42.9 \mathrm{MW}$ were built on as many as 40 livestock farms in Latvia (LBA, 2021); therefore, at least 269 new biogas plants, which use agricultural waste from the 
main livestock industries, could be built. The overall economic impact of the construction of new biogas plants would be as follows:

7) energy dependence on fossil fuels and/or electricity would decrease on each of these farms; 93.5 million $\mathrm{m}^{3}$ of biogas can generate $475568 \mathrm{MW}$ of thermal energy;

8) the biogas remaining for self-consumption on the farm could be purified to biomethane and compressed for subsequent use in transport or sold;

9) the construction of new biogas plants and the installation of related equipment would be performed by local contractors. At least 100 new jobs would be created at the largest biogas plants, as smaller biogas plants would be serviced by current farm workers. In addition, at least 40 other residents of the country would be involved in the maintenance of biogas plants, who would provide repair work services for biogas plant equipment;

10) a feasibility study for the construction of biogas plants (a cogeneration plant, a boiler house, a gas treatment plant) should be done for each farm.

\section{Conclusions, proposals, recommendations}

In 2019 in Latvia, there were 267 farms with 200 and more cattle, 35 farms with 400 and more pigs, 7 farms with 50000 and more poultry, which have the potential to use manure from the livestock production process and unused feed waste for biogas production. Accordingly, it will be possible to produce $93.5 \mathrm{mln} . \mathrm{m}^{3}$ of biogas.

In 2021 in Latvia, 40 livestock farms had biogas cogeneration plants; therefore, it would be maximally possible to build 269 new biogas plants. However, farms should consider cooperating to set up joint biogas plants. The biogas produced could be used locally for heating and transport or for electricity generation. This would increase the country's independence from fossil energy sources, as well as increase the proportion of renewable energy sources to 50-70 \% in final energy consumption by 2030 , thereby create new jobs in rural areas.

\section{Acknowledgements}

The research was promoted with the support of the project Izp-2020/2-0413 "Assessment of the Implementation of the Latvian Bioeconomy Strategy 2030 and Possible Solutions for Achieving the Goals Set (LIBRA-LV)".

\section{Bibliography}

1. Agostini, A., Battini, F., Giuntoli, J., Tabaglio, V., Padella, M., Baxter, D., Marelli, L., Amaducci, S. (2015). Environmentally sustainable biogas? The key role of manure co-digestion with energy crops. Energies, Volume 8 (6), pp. 5234-5265. DOI:10.3390/en8065234.

2. Ahlberg-Eliasson, K. (2017). Production efficiency of Swedish farm-scale biogas plants, p.17-27.

3. Boulamanti, A.K., Maglio, S.D., Giuntoli, J., Agostini, A. (2013). Influence of different practices on biogas sustainability. Biomass Bioenergy, Volume 53, pp. 149-161. DOI:10.1016/j.biombioe.2013.02.020.

4. Central Statistical Bureau (2021a). LLG240. Grouping of Farms of all Kinds by the Number of Cattle and Dairy Cows at End of Year. Retrieved: https://data.csb.gov.lv/pxweb/lv/lauks/lauks_05Lopk_ikgad/LLG240.px/table/tableViewLayout1/ Access: 15.01.2021.

5. Central Statistical Bureau (2021b). LLG250. Grouping of Farms of all Kinds by the Number of Pigs and Breeding Sows at End of Year. Retrieved: https://data.csb.gov.Iv/pxweb/Iv/lauks/lauks_05Lopk_ikgad/LLG250.px/table/tableViewLayout1/ Access: 22.01.2021.

6. Central Statistical Bureau (2021c). LAG020. Sown Area, Total Crop Production, Yield of Agricultural Crops. Retrieved: https://data.csb.gov.Iv/pxweb/lv/lauks/lauks_03Augk_ikgad/LAG020.px/ Access: 24.01.2021.

7. Central Statistical Bureau (2021d). LSSA13_III09. Agricultural Holdings by Number of Poultry. Retrieved: https://data.csb.gov.lv/pxweb/lv/lauks/lauks_skait_apsek_dzivnieki_laukskait_10/LSK10III07.px/table/tableViewLayout1/ Access: 26.01.2021. 
8. European Parliament and the Council (2009). Directive 2009/28/EC On the Promotion of the Use of Energy from Renewable Sources and Amending and Subsequently Repealing Directives 2001/77/EC and 2003/30/EC OJEU, L, 140, pp. 16-62.

9. Hahn, H., Hartmann, K., Bühle, L., Wachendorf, M. (2015). Comparative Life Cycle Assessment of Biogas Plant Configurations for a Demand Oriented Biogas Supply for Flexible Power Generation. Bioresources Technology, Volume 179, pp. 348-358. DOI: 10.1016/j.biortech.2014.12.007.

10. Kaklins, A. (2019). Kutsmesli - terminologija un to nozime lauksaimnieciba (Manure - Terminology and its Role in Agriculture), 22 p. Retrieved: https://zemniekusaeima.lv/wpcontent/uploads/2019/11/K\%C5\%ABtsm\%C4\%93sli-\%E2\%80\%93-terminolo\%C4\%A3ija-un-tonoz\%C4\%ABme-lauksaimniec\%C4\%ABb\%C4\%81_Ozolnieki_2019.pdf. Access: 11.02.2021.

11. Lantz, M., Svensson, M., Bjornsson, L., Borjesson, P. (2007). The prospects for an expansion of biogas systems in Sweden-Incentives, barriers and potentials. Energy Policy, Volume 35(3), pp. 1830-1843. DOI: 10.1016/j.enpol.2006.05.017.

12. Agricultural Data Centre (2020). Public database. July 2020. Retrieved: http://pub.Idc.gov.Iv/pub_stat.php Access: 18.01.2021.

13. Rural Support Service (2021). Apstiprinatas platibas pa kulturam un atbalsta veidiem 2019. gadā. (Areas Approved by Crop and Type of Support in 2019.) Retrieved: https://www.lad.gov.Iv/lv/statistika/platibumaksajumi/periods-2004-2016/statistikas-dati-par-2019-gadu/ Access: 18.01.2021.

14. Latvian Biogas Association (LBA), Zinojums (Latvian Biogas Association, Report), 2021.

15. Ministry of Agriculture of the Republic of Latvia (2008). Kutsmeslu ieguve un apsaimniekosana (Manure Production and Management), 14. p.

16. Mæng, H., Lund, H., Hvelplund, F. (1999). Biogas Plants in Denmark: Technological and Economic Developments. Applied Energy, Volume 64(1-4), pp. 195-206. DOI: 10.1016/S0306-2619(99)00067-7.

17. Nipers A., Pilvere I., Dobele A. (2019). Spatial Analysis of Grassland Utilization Potential in Latvia. In: 19th International multidisciplinary scientific GeoConference SGEM 2019: conference proceedings, Albena, Bulgaria, 30 June-6 July, 2019, Bulgarian Academy of Sciences Sofia, Vol. 19, Issue 5.3: Ecology, economics, education and legislation. Section: Environmental economics, pp. 677-685. DOI: 10.5593/sgem2019/5.3/S21.085.

18. Par Latvijas Nacionalo energetikas un klimata planu 2021.-2030. gadam (2020). Ministru kabineta rikojums Nr. 46, Riga 2020. gada 4. februari (prot. Nr. 4 27. §) (On the National Energy and Climate Plan for 2021-2030. Order of the Cabinet of Ministers No. 46, Riga, 4 February 2020 (protocol No. 4 § 27)), Retrieved: https://likumi.Iv/ta/id/312423-par-latvijas-nacionalo-energetikas-un-klimata-planu-20212030-gadam. Access: 24.01.2021.

19. Patterson, T., Esteves, S., Dinsdale, R., Guwy, A. (2011). Life Cycle Assessment of Biogas Infrastructure Options on a Regional Scale. Bioresources Technology, Volume 102 (15), pp. 7313-7323. DOI: 10.1016/j.biortech.2011.04.063.

20. Poeschl, M., Ward, S., Owende, P. (2010). Prospects for Expanded Utilization of Biogas in Germany. Renewable \& Sustainable Energy Reviews, Volume 14 (7), pp. 1782-1797. DOI: 10.1016/j.rser.2010.04.010.

21. Poeschl, M., Ward, S., Owende, P. (2012). Environmental Impacts of Biogas Deployment-Part II: Life Cycle Assessment of Multiple Production and Utilization Pathways. Journal of Cleaner Production, Volume 24, pp. 184201. DOI:10.3390/en12030532.

22. Potting, J., Hekkert, M., Worrell, E., Hanemaaijer A. (2017). Circular Economy: Measuring Innovation in the Product Chain. English translation of the report 'Circulaire economie: Innovatie meten in de keten', PBL Netherlands Environmental Assessment Agency, The Hague, publication number: 2544, 46 p.

23. Priekulis, J. (2012). Moderna piena razosanas ferma (Modern dairy farm), Jelgava, $216 \mathrm{p}$.

24. Regueiro, L., Carballa, M., Álvarez, J.A., Lema, J.M. (2012). Enhanced Methane Production from Pig Manure Anaerobic Digestion Using Fish and Biodiesel Wastes as Co-substrates. Bioresources Technology, Volume 123, pp. 507-513. DOI: 10.1016/j.biortech.2012.07.109.

25. Risberg, K., Cederlund, H., Pell, M., Arthurson, V., Schnürer, A. (2017). Comparative Characterization of Digestate Versus Pig Slurry and Cow Manure - Chemical Composition and Effects on Soil Microbial Activity. Waste Management, Volume 61, pp. 529-538. DOI:10.1016/j.wasman.2016.12.016.

26. Russo, V., von Blottnitz, H. (2017). Potentialities of Biogas Installation in South African Meat Value Chain for Environmental Impacts Reduction. Journal of Cleaner Production, Volume153, pp. 465-473. DOI: 10.1016/j.jclepro.2016.11.133.

27. Scholz, L., Meyer-Aurich, A., Kirschke D. (2011). Greenhouse Gas Mitigation Potential and Mitigation Costs of Biogas Production in Brandenburg, Germany. AgBioForum, Volume 14, pp. 133-141.

28. Slepetiene, A., Volungevicius, J., Jurgutis, L., Liaudanskiene, I., Amaleviciute - Volunge, K., Slepetys, J., Ceseviciene, J. (2020). The potential of Digestate as a Biofertilizer in Eroded Soils of Lithuania. Waste Management, Volume 102, pp. 441-451. DOI: 10.1016/j.wasman.2019.11.008.

29. Swedish Energy Agency (SEA) (2015). Energy in Sweden. ET015:19, December 2015, Printed by: Arkitektkopia, Bromma, $104 \mathrm{p}$.

30. Uusitalo, V., Soukka, R., Horttanainen, M., Niskanen, A., Havukainen, J. (2013). Economics and Greenhouse Gas Balance of Biogas Use Systems in the Finnish Transportation Sector. Renewable Energy, Volume 51, pp. 132-140. DOI: $10.1016 /$ j.renene.2012.09.002. 